\title{
Bacterias en la hemolinfa de Argopecten purpuratus (Lamark, 1819) (Bivalvia: Pectinidae)
}

\author{
Bacteria in the hemolymph of Argopecten purpuratus (Lamark 1819)
}

(Bivalvia: Pectinidae)

\author{
Patricio García-Tello, Víctor Ardiles y José L. Fajardo \\ Facultad de Ciencias Básicas y Matemáticas, Universidad Católica de Valparaiso, Casilla 4059-Valparaíso, Chile. \\ pgarciat@ucv.cl
}

\begin{abstract}
Twenty three strains of bacteria were isolated from the hemolymph of Argopecten purpuratus.

Our results point out to the predominance of asporogenous
\end{abstract}

Gram-negative rods. We suggest that the presence of these bacteria in the hemolymph is a natural phenomenon.

Key words: bacteria, Mollusca, hemolymph

\section{Introducción}

Los cultivos de ostiones (Argopecten purpuratus) se han desarrollado considerablemente en el país y representan una importante fuente económica para diferentes acuacultores. Estos cultivos son atacados por microorganismos patógenos de diferentes grupos, tales como protozoos (Sellers 2002) $)^{1}$ dinoflagelados y bacterias (Carnegie et al. 1999; Messick et al. 1999; Rivera et al. 1999). Las patologías causadas pueden aparecer en cualquier etapa del desarrollo del cultivo, adulto o larval. Otros sugieren una convivencia entre el molusco y ciertas bacterias (Harris-Young et al. 1993).

Los estados larvales son susceptible a la infección vertical con bacterias, es decir, desde los órganos reproductores (Chávez \& Riquelme 1994). Al parecer la adquisición de una flora bacteriana a nivel de la hemolinfa de invertebrados sería posible fácilmente desde el medio acuático (Brady \& De la Vega 1990; Brady \& De la Vega 1992).

Es importante destacar que también en la hemolinfa conviven sin causar aparentes patologías ciertas bacterias (Costa et al. 1998), las cuales están allí como potenciales patógenos. Estas bacterias están en la hemolinfa, no obstante conocerse que, en algunos invertebrados, por ejemplo, Crassostrea virginica, esta contiene enzimas tipo lisozimas que sirven como un mecanismo de defensa interno (Mc Dade \& Tripp 1967;

\footnotetext{
1 Sellers CL. 2002. Rehabilitation of the Bay (Literally!) through the oyster. Empiricist- Feature Science Articles

http://biology.nebrwesleyan.edu/empiricist/Research/Ecology/Sell ers,Clay/Sellers96.html (Consulta: 15 agosto 2002)
}

Vincent \& Rodrick 2002²). Si bien Riquelme et al. (1995), entregan una lista de bacterias presentes en el ostión, su análisis no menciona bacterias en la hemolinfa. En el presente trabajo pretendemos señalar que ya en los ostiones adultos existen bacterias no sólo en sus gónadas sino que también en la hemolinfa.

\section{Materiales y Métodos}

Del músculo aductor de 3 ejemplares activos de $A$. purpuratus provenientes de linternas en acuacultivo de Pesquera San José en Tongoy (Chile) se obtuvieron aproximadamente $3 \mathrm{~mL}$ de hemolinfa por medio de una jeringa estéril (Terumo). La superficie del músculo fue esterilizada con alcohol antes de obtener la muestra. A partir de esta extracción se sembraron $0,3 \mathrm{~mL}$ de hemolinfa, en placas Petri que contenían Agar Marino ZoBell 2216 y que fueron incubadas a $25^{\circ} \mathrm{C}$ por 7 días. $\mathrm{Al}$ cabo de este tiempo se aislaron al azar 23 colonias que fueron purificadas por sucesivos traspasos en el mismo medio de cultivo. Luego las cepas se sometieron a diferentes pruebas para conocer su:

1) Tinción de Gram y morfología (Tortora et al. 1986)

2) Reacción a la tetrafenil-para-fenilen-di-amina hidroclórica para determinar la presencia de la enzima citocromo oxidasa

\footnotetext{
2 Vincent N \& G Rodrick G. 2002. Micrococcus lysodeikticus sensitive to lysozime treatment from the hemolymph of the American oyster Crassostrea virginica. Journal of Undergraduate Research, University of Florida. http://web.clas.ufl.edu/CLAS/jur/vincentpaper.html (Consulta: 15 agosto 2002)
} 
3) Característica de crecimiento a $25^{\circ} \mathrm{C}$ por 3 días en medio TCBS (Oxoid) para la aislación de bacterias del género Vibrio

4) Característica de crecimiento a $25^{\circ} \mathrm{C}$ por 7 días en medio Hugh-Leifson con glucosa para la reacción de oxidación o fermentación.

\section{Resultados y Discusión}

Los resultados expuestos en la Tabla 1 señalan las morfologías bacterianas de bacillus, cocco-bacillus y cocco Gram-negativos, además de cocco Grampositivos, siendo la flora Gram-negativa la que predomina. Por otra parte, la microflora que forma colonias crema y amarilla, constituye un alto porcentaje (Tabla 1). Costa et al. (1998) aislaron colonias pigmentadas de los géneros Flavobacterium y Cytophaga desde la hemolinfa de un peneido. Así mismo, bacterias Gram-negativas de Pseudomonas que suelen formar colonias mucosas de color crema fueron determinadas por Riquelme et al. (1995) en un estudio bacteriológico de $A$. purpuratus, no obstante este autor no estudió la hemolinfa. Por el contrario, Rivera et al. (1999) también determinaron Pseudomonas en aislaciones hechas de la hemolinfa del crustáceo Callinectes. En general, todo este grupo de bacterias encontradas por otros son Gram-negativas y oxidasa citocrómica positiva. Similar consideración puede hacerse de las bacterias aisladas de la hemolinfa en el presente trabajo.

También sugerimos la presencia de Vibrio, género que fue determinado por Sano \& Tokou (1994) en la hemolinfa de un langostino peneido. Coincidente con nuestros resultados, Olafsen et al. (1993a) y Olafsen et al. (1993b) señalan que la hemolinfa y las estructuras blandas de bivalvos aparentemente saludables, pueden contener bacterias.

La presencia de una cepa de Vibro se ve reflejada en un excelente crecimiento en el medio TCBS a $25^{\circ} \mathrm{C}$. Todas las cepas fueron oxidasa citocrómica positiva y su comportamiento en el medio Hugh-Leifson con glucosa fue aerobio y anaerobio facultativo.

Tabla 1

Caracterización de bacterias aisladas de la hemolinfa de Argopecten purpuratus

Characterization of bacteria from Argopecten purpuratus hemolymph

\begin{tabular}{clcclcc}
\hline $\begin{array}{c}\text { Bacteria } \\
\mathbf{N}^{\mathbf{0}}\end{array}$ & $\begin{array}{c}\text { Morfología } \\
\text { celular }\end{array}$ & $\begin{array}{c}\text { Tinción } \\
\text { Gram }\end{array}$ & $\begin{array}{c}\text { Oxidasa } \\
\text { citocrómica }\end{array}$ & $\begin{array}{c}\text { Hugh-Leifson } \\
\text { con glucosa }\end{array}$ & $\begin{array}{c}\text { Crecimiento en } \\
\text { TCBS }\end{array}$ & $\begin{array}{c}\text { Color de la } \\
\text { colonia }\end{array}$ \\
\hline 1 & bacillus & - & + & Anaerobio facultativo / Ox & - & Crema \\
2 & bacillus & - & + & Anaerobio facultativo / Ox & - & Crema \\
3 & cocco-bacillus & - & + & Aerobio / Ox & Crema \\
4 & cocco & - & + & Sin crecimiento & - & Amarilla \\
5 & cocco-bacillus & - & + & Aerobio / Ox & - & Crema \\
6 & cocco & - & + & Anaerobio facultativo / F & + & Crema \\
7 & cocco & - & + & Aerobio / Ox & - & Naranja \\
8 & cocco-bacillus & - & + & Anaerobio facultativo / Ox & - & Crema \\
9 & cocco-bacillus & - & + & Aerobio / Ox & - & Crema \\
10 & bacillus & - & + & Sin crecimiento & - & Amarilla \\
11 & bacillus & - & + & Sin crecimiento & - & Crema \\
12 & cocco & - & + & Microaerófilo / Ox & - & Crema \\
13 & cocco & - & + & Anaerobio facultativo / Ox & - & Amarilla \\
14 & bacillus & - & + & Sin crecimiento & - & Amarilla \\
15 & cocco & + & + & Anaerobio facultativo / F & + & Crema \\
16 & cocco-bacillus & - & + & Anaerobio facultativo / Ox & - & Amarilla \\
17 & bacillus & - & + & Sin crecimiento & Crema \\
18 & cocco-bacillus & - & + & Microaerófilo / Ox & - & Crema \\
19 & cocco & - & + & Anaerobio facultativo / Ox & - & Crema \\
20 & cocco-bacillus & - & + & Anaerobio facultativo / Ox & - & Amarilla \\
21 & cocco & + & + & Anaerobio facultativo / Ox & - & Crema \\
22 & cocco-bacillus & - & + & Anaerobio facultativo / Ox & - & Naranja \\
23 & cocco & + & + & Anaerobio facultativo / Ox & - & \\
\hline
\end{tabular}

Gram positivo $=+$ Gram negativo $=$ -

presencia de oxidasa citocrómica $=+\mathrm{Ox}=$ oxidativo

$F=$ fermentativo

crecimiento positivo en TCBS $=+\quad$ crecimiento negativo en TCBS $=$ - 
Podemos sugerir que la presencia de bacterias en la hemolinfa de $A$. purpuratus es un fenómeno natural tal como se ha informado por Riquelme et al. (1995) para las gónadas de este mismo bivalvo. Además, predomina la presencia de bacterias Gram-negativas y entre ellas las bacterias de morfología de bacillus, cocco y coccobacillus. Por otra parte, Vincent \& Rodrick (2002) demuestran, en forma experimental, la actividad lítica de lisozimas de la hemolinfa de un bivalvo contra cierta bacteria Gram-positiva. Posiblemente los hemocitos realizan una labor retardada en la eliminación de bacterias desde la hemolinfa y son favorecidas en la invasión de esta por fenómenos de estrés muy propio de los cultivos marinos.

\section{Agradecimientos}

Nuestros agradecimientos a la Dra. Gloria Arenas por habernos proporcionado una parte de los ostiones usados en su laboratorio y al Sr. Ricardo San Martín por su colaboración técnica. También los autores agradecen la dedicación con que los anónimos correctores contribuyeron a mejorar esta nota científica.

\section{Literatura Citada}

Brady YJ \& EL De la Vega. 1992. Recovery of Serratia marcescens in hemolymph of Macrobrachium rosenbergii from experimentally seeded water. Journal of the World Aquaculture Society 23: 228-231.

Brady YJ \& EL De la Vega. 1990. Communication. Bacteria in the hemolymph of the freshwater prawn Macrobrachium rosenbergii. Journal of Aquatic Animal Health 4: 67-69.

Carnegie RV, BJ Barber, DL Distel \& D Culloty. 1999. Development of PCR and in situ hybridisation assay for detection of Bonamia ostreae in flat oyster, Ostrea edulis. Journal of Shellfish Research 18: 711-712.

Chávez P \& C Riquelme. 1994. Análisis de la calidad bacteriológica en reproductores de Argopecten purpuratus (Lamark, 1819) para su uso en acuicultura. Revista Latinoamericana de Acuicultura 43: 96-99.
Costa R, I Mermound, S Cloblavi, B Morlet, P Haffner, F Berthe, M Legroumellec \& $P$ Grimont. 1998. Isolation and characterization of bacteria associated with a Penaeus stylirostris disease in New Caledonia. Aquaculture 164: 297-309.

McDade J\& M Tripp. 1967. Lysozyme in the hemolymph of oyster, Crassostrea virginica. Journal of Invertebrate Pathology 9: 531-535.

Harris-Young L, ML Tamplin \& WS Fisher. 1993. Effects of physicochemical factors and bacterial colony morphotype on association of Vibrio vulnificus with hemocytes of Crassostrea virginica. Applied and Environmental Microbiology 59: 1012-1017.

Messick GA, SJ Jordan \& WF Van-Heukelem. 1999. Salinity and temperature effects on Hematodinium sp. in the blue crab Callinectes sapidus. Journal of Shellfish Research 18: 657-662.

Olafsen JA , HV Mikkelsen, HM Giaever, \& GH Hansen. 1993a. Indigenous bacteria in hemolymph and tissues of marine bivalves. Journal of Fish Biology 40: 141-156.

Olafsen JA, V Lund \& Tunkijjanukij Suriyan. 1993b. Lectins and pentraxins from marine invertebrates and fish: Ligands and functions? Journal of Fish Biology 40: 120125.

Riquelme C, L Hayashida, N Vergara, A Vásquez, Y Morales \& P Chávez. 1995. Bacteriology of the scallop Argopecten purpuratus (Lamarck, 1819) cultured in Chile. Aquaculture 138: 49-60.

Rivera A, K Santiago, J Torres, MP Sastre, \& FF Rivera. 1999. Bacteria associated with hemolymph in the crab Callinectes bocourti in Puerto Rico. Bulletin of Marine Science 64: 543-548.

Sano T \& T Tokou. 1994. The primary hemocyte culture of kuruma shrimp Penaeus. International Symposium on Biotechnology, applications in aquaculture, Taipei, Taiwan: 32-33.

Tortora GJ, BR Funke \& CL Case. 1986. Microbiology An Introduction. 3: 59-78. The Benjamin/Cummings Publishing Company, Inc. California. 